\title{
STUDENT FUNDING AND STUDENT SUCCESS: A CASE STUDY OF A SOUTH AFRICAN UNIVERSITY
}

\author{
A. Naidoo \\ Gordon Institute of Business Studies \\ University of Pretoria, and \\ University of the Free State \\ South Africa \\ e-mail: Anban.Naidoo@up.ac.za
}

\section{T. J. M. McKay}

Department of Environmental Science

University of South Africa

Pretoria, South Africa

e-mail: mckaytjm@unisa.ac.za

\section{ABSTRACT}

The 2015/16 \#FeesMustFall protests brought the insufficient tertiary-level student funding problem into the national consciousness, with students arguing they are being excluded from higher education as they do not have sufficient funds. But, the relationship between academic success and access to student funding is not clear. Thus, this study sought to contribute clarity to our understanding of the relationship between student bursary funding and academic performance. Methodologically, it involved an analysis of 8099 undergraduates for the 2011 cohort year. This 2011 cohort was tracked over a period of three years, a period considered as minimum time to gradation. Results show that was no relationship between students being awarded a bursary, and their successful graduation (throughput). Nor was there any relationship between the value of bursary awarded and students' academic performance. Furthermore, the presence of genuine outliers in the dataset is an indication that the allocation of bursary money to individual students must be made more transparent and accountable. In terms of the cohort under study it can be concluded that student academic performance was not a function of bursary funding, although merit bursaries awarded on academic merit yielded the best results. We conclude that student funding is a complex and challenging function, and cannot be viewed as a simple action of funding financially needy students. The limitations of the study should also be noted: it was confined to one large contact institution of higher education and it does not capture those students who take four or more years to complete their qualification.

Keywords: student funding, student academic success, predictors of success, student residence 


\section{INTRODUCTION}

Higher education is linked to economic mobility, so although South Africa has 26 public tertiary institutions (including three new tertiary institutions), demand for access and funding for public tertiary education far exceeds supply. In terms of access, part of the problem is that although the number of higher education students has drastically increased in the last 10 years, peaking in 2011, all universities are now subjected to strict enrolment plans (DHET 2013). Thus enrolment numbers are capped. So, some students will have their applications declined even though they may qualify for admission (Walker and Mkwananzi 2015). But, there are additional hurdles for those who are admitted, in that they will not necessarily be in a position to pay their fees. While some qualify for standalone independent bursaries from industry or other donors, and others qualify for National Student Financial Aid Scheme (NSFAS) funding, there are those who do not. The NFSAS is a funding scheme that has been in operation since 1999 but has rigorous terms and conditions. Namely: (1) only those whose incomes fall into the lowest tax bracket qualify for funding, or (2) they must have attended a designated "no fee" school, or (3) they must reside in municipalities deemed to be priority districts, that is, financially marginal or deprived (Sader and Gabela 2017).

So, although NSFAS assists many disadvantaged students, there are still significant funding shortfalls and financial exclusions (Koen, Cele and Libhaber 2006; Pillay 2010; Sader and Gabela 2017). Nevertheless, even this NSFAS funding is mostly a loan - with only 40 per cent of the amount converted into a bursary, and the only if the student performs well academically (Lebeau et al. 2012). In addition, there might be those who are not aware that funding support is available and so do not apply (Callender and Wilkinson 2013; Walker and Mkwananzi 2015). Thus, many go unfunded. Part of the problem is that demand for funding has reached excessive levels due to the combination of university fees having increasing dramatically alongside a massive increase in enrolment numbers (DHET 2013). The explosion of the \#FeesMustFall protests in 2015/16 put this national student funding crisis firmly in the headlines and into the consciousness of the general publics (Hodes 2017).

South African students without bursaries have to seek out bank loans or rely on part-time work, savings and parental or family contributions to pay for their studies (Callender and Jackson 2008; Richardson, Evans and Gbadamosi 2009). But not all qualify for bank loans, or can find part-time work and some do not have family who can support them. Importantly, tertiary education is very expensive for most South Africans as there are many additional nontuition costs such as living expenses, textbooks and other academic related costs (such as internet access), transport costs and lifestyle costs (Oyelana 2017). Importantly, \#FeesMustFall highlighted the funding challenges the so-called "missing middle" face as they cannot get 
NSFAS funding but also do not come from homes which can afford the fees charged by tertiary institutions.

As a result, it is claimed that many of the 50 per cent of students who drop out of higher education institutions in South Africa do so for financial reasons (Styan 2014). So, it is argued that students are being excluded from higher education due to insufficient funds. Consequently, there is great pressure on universities to help such students, so funding tertiary students is now a top priority (Aydin 2014). In many cases, institutions of higher education are now forced to (somehow) find money or risk riots, violent disruptions and reputational damage if they do not. That this is unsustainable has been reported by many Vice Chancellors, one of whom is Prof. Ihron Rensburg of the University of Johannesburg (Jansen 2017).

In particular, universities are faced with competing priorities and certainly not all funds can be simply re-directed to student bursaries (Moloi and Motaung 2014). In general, universities are facing acute funding shortfalls, as they have been inadequately funded by the State; with State's contribution to university budgets falling to only 40 per cent in $2012 .{ }^{1}$ Thus, many universities are dealing with operating deficits, as they battle to pay salaries, maintenance, library acquisitions and even services such as water and lights (Maistry and McKay 2016; Qonde 2016). Consequently, in terms of universities assisting unfunded students, there is significant pressure to ensure that funds awarded to the right student at the right time (HarrisonWalker 2010; Badat 2016). This implies a balance between economic need, meeting transformational criteria and throughput.

Given the need for funding to assist students to convert their educational aspirations into reality, as well as pressure on tertiary institutions to use their own resources to effect transformation, the current student funding model and its challenges needs to be explored (Badat 2016; Walker and Mkwananzi 2015). In particular, although various models of student funding currently exist in South Africa, no specific model has been explicitly and formally implemented within the higher education sector. Furthermore, despite the extensive funding problems, there are significant gaps in the literature on student funding, bursary allocations, and bursaries in general with respect to South Africa (although there are related studies in the United States of America, United Kingdom and Asia) (Curtis and Kiapper 2005; Harrison and Hatt 2012; Kerkvliet and Nowell 2014; Harrison, Agnew and Serido 2015; Panigrahi 2015). Additionally, the results of what little research there is, are mixed. In England there seems to be little evidence of a positive relationship between student funding and academic success, whilst in Germany the opposite was found (Glocker 2011; Harrison and Hutt 2012).

Lastly, few studies have explored the relationship between student bursary funding and academic success in South Africa (Welsch and Zimmer 2012; Delaney, Harmon and Ryan 
2013; Bai, Chi and Qian 2014). This then is an attempt to partially address this gap. Thus, the purpose of this research was to explore the current student funding model, to gain an understanding the current funding challenges and attempt to find ways in which funding decisions can be improved.

\section{STUDENT FUNDING}

Between the 1990's and early 2000's, national student debt in South Africa rose to R5.5 Billion² as university fees increased (due to reduction in subsidies from government), but little pressure was placed on student or graduates to pay their student debt. Consequently, many institutions faced bankruptcy, which was only "solved" by a political decision (by the then Minister of Education, Prof Kadar Asmal) to merge financially stressed institutions (mostly these were historically disadvantaged or institutions formerly for people of colour) with financially stronger ones (mostly these were historically advantaged or former white institutions). Subsequently, universities began demanding upfront payments. Other cost recovery strategies, such as aggressive debt collection, also became the norm in order to avert future cash flow problems. In some cases, institutions even resorted to withholding academic results to force students to pay up (Koen et al. 2006).

Unfortunately, rising costs and reduced funding have made higher education in South Africa more exclusive, with only students who have access to funds able to enrol and persist in their studies (Bozalek and Boughey 2012). Against this backdrop, huge pressure was placed on the state and the universities by the \#FeesMustFall movement, which demanded that higher education should be far better funded than it is. More radical elements of this movement are even calling for totally free higher education (Cloete 2016). How realistic these demands are within the context of other financial obligations on the South African state, and the poor performance of the South African economy in the long term has yet to be determined. Nevertheless, there are concerns that the attention paid to increasing financing should not overshadow research that has shown that while financial aid has a positive impact on student academic performance, it cannot be said that more money per student automatically results in greater academic success (Richardson et al. 2009). Importantly, Koen et al. (2006) argue that disadvantaged students do not fail only because of financial issues. They also face significant challenges in coping with the academic programme. Part of the problem is that they often suffer from poor quality basic education whereby they enter university poorly prepared for advanced studies. In addition, it may be that some students enrol because of the offer of financial assistance and not necessarily because they are intrinsically motivated to acquire a tertiary education (Harrison and Hutt 2012). Lastly, some have argued that poor course choice is a 
serious issue and strongly correlated with drop-out due to low levels of motivation and commitment (Harrison 2006; Farsides and Woodfield 2007).

\section{THE ADMISSIONS PROCESS}

As much of the student funding decision is linked to admissions criteria, it is important that institutions have an admission process that correctly identifies the financially needy, who also have the most potential for academic success, whilst still taking transformational and access issues into account. Transformation and access imperatives are crucial, as universities are compelled by the Higher Education Act (No 101, 1997) to have admission policies and criteria that support broad access and transformation (NDoE 1997; Koch and Foxcroft 2003). However, most universities place great emphasis on academic criteria, usually assumed in South Africa, to be school marks, known as the final matriculation mark (Zaaiman 1998). In addition, there are other academic criteria, such as mathematics for example (Al-Twaijry 2010). However, academic measures of success are contested. Some studies show that while academic measures had strong correlations to academic performance one university, the same ones had only weak correlations to performance at another university (Al-Twaijry 2010). In the South African context, many studies have shown that matriculation results are somewhat unreliable predictors of success at tertiary level (Van Eeden, De Beer and Coetzee 2001; Koch and Foxcroft 2003; Fraser and Killen 2005; Van der Merwe and De Beer 2006; Enslin et al. 2006; Cliff and Hanslo 2009; McKay 2016a). Consequently, tests such as the National Benchmarking Tests (NBT) have been touted as possible tools that can be used to supplement matriculation results (Biggs 2003; Grussendorff, Liebenberg and Houston 2004; Van der Merwe and De Beer 2006; Fleisch, Schöer and Cliff 2015). Others maintain that attitudes and behaviours have a strong effect on a student's progress within the institution and, as such, should be taken into account (HarrisonWalker 2010; Westerman et al. 2011; McKay 2016b). These are known as non-academic criteria, which, to date, have not gained much traction with South African institutions in terms of adapting them as part of the admissions criteria.

\section{METHODOLOGY}

The aim of this research was to conduct an exploratory study into the current South African undergraduate student funding model employed by one institution of higher education for the purposes of improving efficiency and effectiveness. Thus, this research set out to establish if there is a relationship between the awarding of student funding and student academic success. Measuring success is always contentious. Some argue that lecture attendance; language proficiency and study habits should be used to measure success (Delaney, Harmon and Ryan 
2013). Other scholars are of the opinion that a student's ability to be employed is a better measure of success (Phelan and Mills 2011; Dos Santos Martins, Correia Loureiro and Castro Amorim 2013). This study, however, relied on the two main ways in which higher education institutions measure student academic success. These are: tracking average student results for the year of study, and the number of students who complete their studies in the minimum time (Al-Twaijry 2010).

For this study a cohort of first year students was tracked over a three-year period, as this is the minimum number of years to complete an undergraduate degree. As such only three-year degree programmes were considered. In this regard, some 8099 students were enrolled (across all degree programmes) at this contact higher education institution in 2011. Of these, 7182 were enrolled in 2012 and 6652 were enrolled in 2013. The secondary data was supplied by the university itself; and, as the university uses this data for multiple purposes, the data is collected with a high degree of rigour. Access to the secondary data was granted by the Registrar of the institution and the Directors: Academic Administration and Student Finance. Meetings were held with these respective staff to make data cleaning decisions. Ethics clearance was sought and granted by the institution. Outliers were included in the analysis as they were genuine data points and not due to data entry or measurement errors.

The secondary data that was used were Tertiary Academic Results (Grade Point Averages or GPA) for $1^{\text {st }}(2011), 2^{\text {nd }}(2012)$ and $3^{\text {rd }}$ (2013) years of study, and Academic status (Dismissal, Complete, and Discontinued). The GPA represents the average of the grades obtained for modules the student was registered for at an institution of higher education. It is also weighted by the credits allocated to the modules in question. This weighting is undertaken as it provides a better reflection of a student's performance since the credits are based on duration and complexity of the module. It is regarded as a best practice benchmark internationally. In terms of student funding, the aggregated student funding amounts for each year was tested against the GPA for the relevant year of study. There are three different types of student funding: (1) The universities own funds (merit bursaries, sport bursaries, special projects, S-Fund bursaries, family discounts, staff rebates, Edu-loan and university loans), (2) Funds controlled by the university (NSFAS, studentships and external donors); and (3) Funds administrated by the university (bursaries from the local municipality, provincial government, national government and other external donors). Each fund has a variety of requirements or criteria that must be met before funds are awarded (see Table 1). As the research was only conducted at a single South African institution of higher education, and focused solely on student funding for the 2011 undergraduate cohort, further research needs to be conducted to determine if the results are generalizable to the whole South African student population. 
Table 1: List of criteria used to determine if a student qualifies for funding

\begin{tabular}{|c|c|}
\hline Academic Criteria & Non-Academic Criteria \\
\hline $\begin{array}{l}\text { - Grade } 12 \text { Results (Individual subjects, } \\
\text { Admissions Point Score, etc.) } \\
\text { - Grade Point Average }\end{array}$ & $\begin{array}{ll}\text { - } & \text { Financial Neediness } \\
\text { - } & \text { Sports Achievement } \\
\text { - } & \text { Extra-curricular activities especially leadership } \\
& \text { (Head boy/girl, etc.) } \\
\text { - } & \text { Employment Status (Institutional Staff) } \\
\text { - } & \text { Disability Status } \\
\text { - } & \text { Application for funding } \\
\text { - } & \text { Faculty and/or Study choice } \\
\text { - } & \text { Population Group/Race } \\
\text { - } & \text { School } \\
\text { - } & \text { Loyalty (Development or school programmes) }\end{array}$ \\
\hline
\end{tabular}

\section{RESULTS: STUDENT FUND ALLOCATIONS AND STUDENT SUCCESS RATES}

The aggregated student funding amount for each year was tested against the GPA for the relevant year of study. Results are displayed in scatter plot diagrams. Thereafter, the relationship between individual funds was explored. There were outliers but hey were included in the analysis as they are genuine data points. The following relationships were tested: (1) 2011/2012/2013 Funding and 2011/2012/2013 GPA; (2) 2011/2012/2013 Internal Funding and 2011/2012/2013 GPA; (5) 2011/2012/2013 Institution Controlled Funding and 2011/2012/2013 GPA; (6) 2011 Institution Administered Funding and 2011/2012/2013 GPA and (7) All 2011/2012/2013 Individual Funds and 2011/2012/2013 GPA. For the purposes of this research, 2011, 2012 and 2013 refer to the 1st, 2nd and 3rd years of study.

It was found that, due to the manner in which money is distributed, the data is clustered generally below R50 000, with particular clusters between R0 to R5 000. That is, many students get small amounts of money and a few get large amounts. There are genuine outliers in the database, which are of concern, as seemingly some students receive far more money than most. It was found that there was no relationship between the awarding of bursaries in 2011 and 2011 GPA, with a correlation of $.173^{* *}[\mathrm{p}=0.00$ on the Pearson two-tailed $\mathrm{t}$ test, $\mathrm{n}=1935]$ (see Figure 1).

The second relationship that was tested was between the 2012 bursaries and the 2012 GPA. Once more, the data are clustered below R 50000 and in particular clustered between R 0 to R 5 000; but the substantially more extreme data points indicate specific students receiving more than R 100000 in bursary money. Once again, this is far in excess of what the typical student was receiving. But, for 2012, there was some differentiation in the results. There was a correlation of $.556^{* *}$ for the 2012 GPA and 2012 Internal Merit Bursary allocations $[\mathrm{p}=0.00$ on the Pearson two-tailed $\mathrm{t}$ test, $\mathrm{n}=695$ ] but a correlation of $-0.453 * *$ for the 2012 GPA and 2012 Government bursaries administered by the institution $[\mathrm{p}=0.00$ on the Pearson two-tailed 


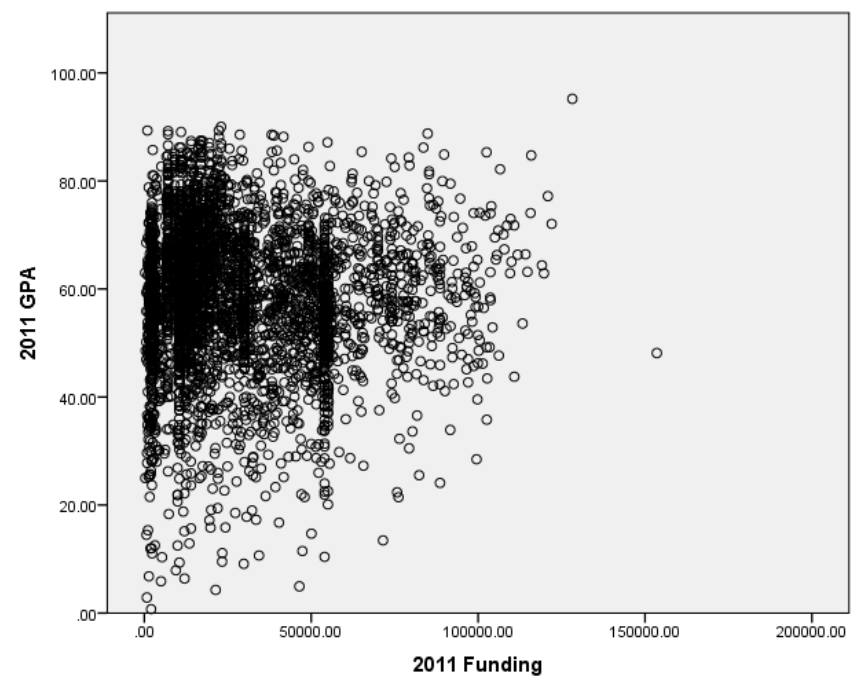

Figure 1: Scatter plot of 2011 Bursary Funding and 2011 GPA (academic results)

$\mathrm{t}$ test, $\mathrm{n}=37]$. Thus, there is a moderate-strong relationship for Internal Merit Bursary bursaries, but an inverse one for NFSAS bursaries administered by the institution (see Figure 2). Overall, it can be said that the relationship between funding and GPA is moderate at best, with serious concerns about the effectiveness of NFSAS bursaries.

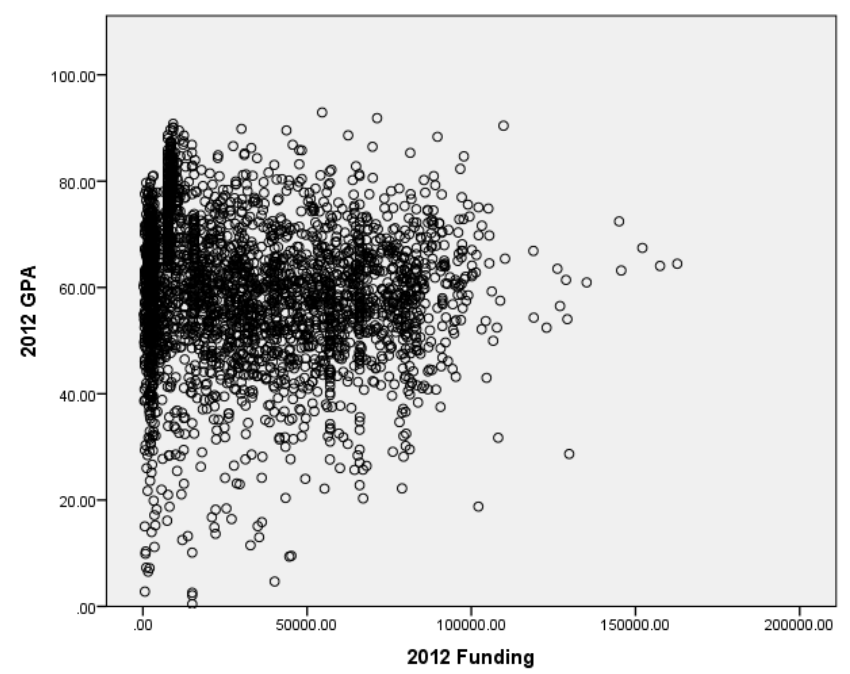

Figure 2: Scatter plot of 2012 NFSAS Funding and 2012 GPA (academic results)

The third relationship that was tested was that between 2013 Funding and 2013 GPA. The outliers were still genuine data points, but in this case there were many more of them. For 2013, the relationship of GPA to Internal Merit Bursaries was weak with a correlation of $.380 * *[p=$ 0.00 on the Pearson two-tailed t test, $n=452]$. For institution project controlled funding, the relationship was also weak with a correlation of $.382^{* *}[\mathrm{p}=0.160$ on the Pearson two-tailed $\mathrm{t}$ test, $\mathrm{N}=15$ ] and for institution administered loan funding the relationship was moderate with a 
correlation of $.498^{* *}[\mathrm{p}=0.003$ on the Pearson two-tailed t test, $\mathrm{n}=33]$ (see Figure 3). Although both institution controlled funding and institution administered loan funding have a weakmoderate correlation, there was no linear relationship. Important, as Figure 4 shows, there was a strong linear relationship between 2013 Merit Bursaries and 2013 GPA, with only five data points posing as outliers.

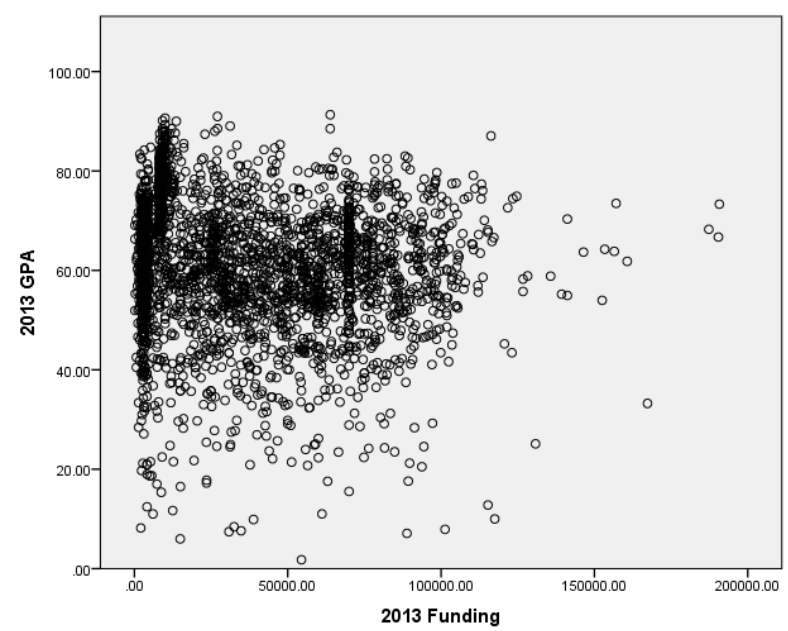

Figure 3: Scatter plot of 2013 Funding and 2013 GPA (academic results)

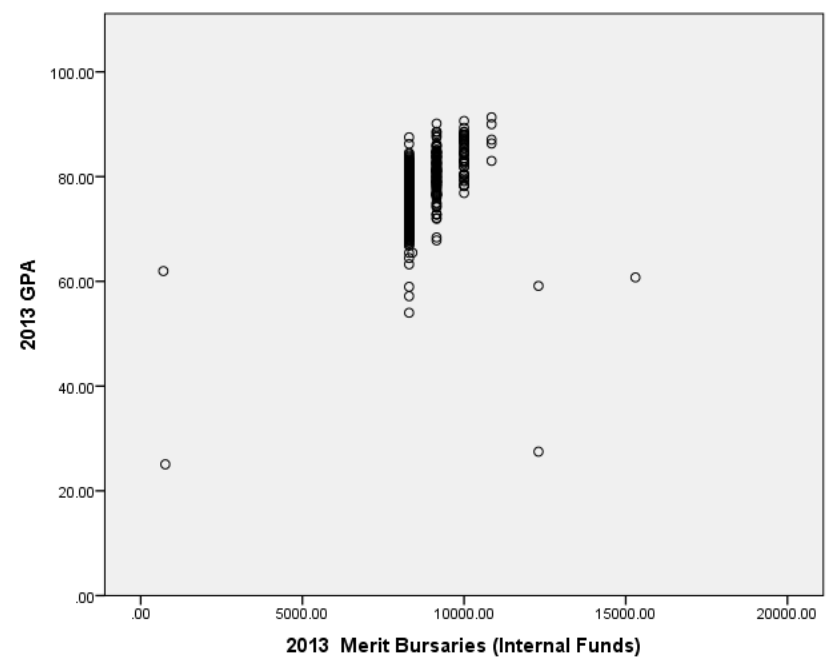

Figure 4: Scatter plot of 2013 Merit Bursaries and 2013 GPA

Thus, a strong relationship exists between the amount of funds allocated for merit bursaries and academic performance (see Table 2). With Merit bursaries awarded based on performance in the previous year of study, this finding indicates that supporting the academically best students is a good investment. This supports other findings that institutions need to pick the right student to whom to award financial support (Harrison-Walker 2010). 
Table 2: Correlation between GPA and Merit Bursaries

\begin{tabular}{|l|l|l|}
\hline \multicolumn{2}{|c|}{} & 2011 Merit Bursaries \\
\hline \multirow{3}{*}{2011 GPA } & Pearson Correlation & $.173^{\text {** }}$ \\
\cline { 2 - 3 } & Sig. (2-tailed) & .000 \\
\cline { 2 - 3 } & N & 1935 \\
\hline \multirow{3}{*}{2012 GPA } & Pearson Correlation & 2012 Merit Bursaries \\
\cline { 2 - 3 } & Sig. (2-tailed) & $.556^{* *}$ \\
\cline { 2 - 3 } & N & .000 \\
\hline \multirow{3}{*}{2013 GPA } & Pearson Correlation & 695 \\
\cline { 2 - 3 } & Sig. (2-tailed) & 2013 Merit Bursaries \\
\cline { 2 - 3 } & N & $.380^{* *}$ \\
\hline
\end{tabular}

But, that said, this relationship is not as strong it could be. This is to say that financial strain is just one of the stresses that students are exposed to (Kinnucan, Zheng and Brehmer 2006; Paliulis and Labanauskis 2015). Therefore, further research is needed in this area to understand and improve the relationship between the merit bursary amount and academic performance to ensure that the amount allocated matches the predicted success of the student.

\section{DISCUSSION}

The study reveals that there are numerous challenges with the current funding mechanism. The existence of real outliers is especially a concern, as some students are clearly being awarded multiple or high value bursaries, totally unrelated to their academic performance. This needs investigation to determine how such a situation came about. As all of these bursaries are administered through the university, the university itself is in a good position to flag this with respective funders. In addition, and deeply problematically, the results also show that there are also many cases where students perform well academically but do not receive adequate funding. Importantly, with the exception of funding based on academic performance, the study found no relationship between the amount funded and the academic success of a student. That is, in the case of the cohort under study, the only funding that showed a positive relationship were the academic merit bursaries. Money awarded based on the criteria "neediness" did not show a relationship with student performance. That is, there was no relationship between the amount funded and the academic success of a student. This may be a consequence of focussing too heavily on financial neediness alone as criteria for funding. In addition, based on the findings presented here, the value of awarded bursaries in the first year of study seems problematic. That is, most funding decisions are made upon application to study at the university and so are based on the matriculation results, which may not be a good indicator of academic success in tertiary 
studies. Thus, it is recommended that additional research is undertaken into determining which first year students should be funded.

In terms of NSFAS, the value of the funding was inversely correlated with academic success. Thus, it may be that NFSAS is indebting students without enabling them to gain a tertiary qualification. In particular, low income students may be profoundly underprepared for university study. So, simply funding such students without putting measures in place to build their capacity for tertiary study is unproductive. Therefore, this study presents data that suggests that funding alone is not the solution to tertiary education drop-out rates. This finding concurs with that of Forster (2008) who indicated that simply assisting a student with a funding problem does not necessarily result in improved academic results. It is also in line with the findings of Dewey (2009) where the amount of bursary funding does not necessarily equate to better academic performance.

Thus, any student funding model needs to carefully consider what additional factors can be used to allocate funding. That is, due to the many strategic considerations that have to be taken into account when it comes to student funding, the current model is ineffective. This finding is in line with that of Mngomezulu, Dhunpath and Munro (2017) who also concluded that alternative funding models are required. The multiple funding groups and large number of individual funds that have to be administered, along with multiple or varying criteria, has made the administration of bursaries extremely complex and perhaps resulted in disassociation with cumulative academic success. In particular, a revision of admissions decisions which are currently based solely on Grade 12 academic results may be required. There is evidence that using non-academic performance criteria to allocate funding may be an option worth considering (Delaney, Harmon and Ryan 2013). So, much more research will be required in terms of how to ensure an improved the return on investment for the bursar. In particular, strategic considerations should focus on how to maximise the impact of the limited funding available, rather than on simply finding more money for all financially needy students (Forster 2008). It may be possible that by allocating funding more effectively, academic performance will be enhanced (Kinnucan et al. 2006).

\section{CONCLUSION}

This study has demonstrated that student funding is complex and challenging. It should not be viewed as a simple action of funding financially needy students. This finding is somewhat different to the populist view presented by the \#FeesMustFall movement, but in line with much published international research. Furthermore, the existence of outliers in the dataset indicates that better, more strategic considerations need to be made when allocating bursary money to 
individual students. Lastly, the funding model applied to first years in particular needs to be reviewed, and the university has to put measures in place to capacitate underprepared students if academic success is to be promoted.

\section{ACKNOWLEDGEMENTS}

This article is in part drawn from the thesis by A. Naidoo 2015, student funding at a South African institution of higher education, Gordon Institute of Business Studies, University of Pretoria, Masters of Business Administration.

\section{NOTES}

1. Student fees: facts, figures and observations http://www.fin24.com/Economy/Student-fees-factsfigures-and-observations-20151022 Accessed 15 Sept 2017.

2. In 2000 the USD exchange rate was R6.72 to one USD.

\section{REFERENCES}

Al-Twaijry, A. A. 2010. Student academic performance in undergraduate Managerial-Accounting Courses. Journal of Education for Business 85(6): 311-322. http://doi.org/10.1080/ 08832320903449584

Aydin, H. 2014. A comparative study between the United States and Turkey on teachers' lesson planning effort. Revista de Cercetare si Interventie Sociala 46: 99-117.

Badat, S. 2016. Deciphering the meanings, and explaining the South African higher education student protests of 2015-16. https://wiser.wits.ac.za/system/files/documents/Saleem\%20Badat $\% 20$ $\% 20$ Deciphering\%20the $\% 20$ Meanings $\% 2 \mathrm{C} \% 20$ and $\% 20$ Explaining\%20the $\% 20$ South $\% 20$ Africa n\%20Higher\%20Education\%20Student\%20Protests.pdf (Accessed 12 Sept 2018).

Badat, S. and Y. Sayed. 2014. Post-1994 South African education: The challenge of social justice, Annals of the American Academy of Political and Social Science 652: 127-148.

Bai, C., W. Chi and X. Qian. 2014. Do college entrance examination scores predict undergraduate GPAs? A tale of two universities. China Economic Review (1043951X) 30: 632-647. http://doi.org/10.1016/j.chieco.2013.08.005

Biggs, J. 2003. Teaching and quality learning at university. $2^{\text {nd }}$ edition. Bell \& Bain, Glasgow.

Bozalek, V. and C. Boughey. 2012. (Mis)framing higher education in South Africa. Social Policy \& Administration 46(6): 688-703. http://doi.org/10.1111/j.1467-9515.2012.00863.x

Callender, C. and J. Jackson. 2008. Does the fear of debt constrain choice of university and subject of study? Studies in Higher Education 33: 405-29.

Callender, C. and D. Wilkinson. 2013. Student perceptions of the impact of bursaries and institutional aid on their higher education choices and the implications for the National Scholarship Programme in England. Journal of Social Policy 42(02): 281-308. http://doi.org/10.1017/ S0047279412000992

Cliff, A. and M. Hanslo. 2009. The design and use of "alternative" assessments of academic literacy as selection mechanisms in higher education, Southern African Linguistics and Applied Language Studies 27(3): 265-276.

Cloete, N. 2016. Free higher education: Another self-destructive South African policy. Centre for Higher Education Trust. http://chet.org.za/files/Higher\%20education\%20and\%20Self\%20destructive\% 20policies\%2030\%20Jan\%2016.pdf (Accessed 16 March 2016). 
Curtis, S. and R. Kiapper. 2005. Financial support systems: The student experience in England and France. International Journal of Social Economics 32(1/2): 121-132.

Delaney, L., C. Harmon and M. Ryan. 2013. The role of noncognitive traits in undergraduate study behaviours. Economics of Education Review 32: 181-195. http://doi.org/10.1016/j.econedurev. 2012.07.009

Dewey, B. I. 2009. Through any means available: Connecting people with scholarship. Journal of Library Administration 49(5): 533-544. http://doi.org/10.1080/01930820903090912

Department of Higher Education and Training. 2013. Statistics on post-school education and training in South Africa: 2013. http://www.dhet.gov.za/ SitePages/Doc_Publications.aspx

DHET see Department of Higher Education and Training.

Dos Santos Martins, H., S. M. Correia Loureiro and M. P. Castro Amorim. 2013. Quality and sustainability in higher education institutions: Key factors. International Journal of Management Cases 15(4): 315-330.

Enslin, P. A., A. Button, M. Chakane, M. de Groot and L. Dison. 2006. Assessing academic potential for university admission: The biographical questionnaire. South African Journal of Higher Education 20(4): 433-448.

Farsides, T. and R. Woodfield. 2007. Individual and gender differences in "good" and "firstclass" undergraduate degree performance. British Journal of Psychology 98: 467-483.

Fraser, W. and R. Killen. 2005. The perceptions of students and lecturers of some factors influencing academic performance at two South African universities. Perspectives in Education 23(1): 25-40.

Forster, G. 2008. Free marketeers should support student-centred funding. Economic Affairs 28(2): 74 75. http://doi.org/10.1111/j.1468-0270.2008.826_b.x

Fleisch, B., V. Schöer and A. Cliff. 2015. When signals are lost in aggregation: A comparison of language marks and competencies of first-year university students. South African Journal of Higher Education 29(5): 156-178.

Glocker, D. 2011. The effect of student aid on duration of study. Economics of Education Review 30(1): $177-90$.

Grussendorff, S., M. Liebenberg and J. Houston. 2004. Selection for the Science Foundation programme (University of Natal): The development of a selection instrument, South African Journal of Higher Education 18(1): 265-272.

Harrison, N. 2006. The impact of negative experiences, dissatisfaction and attachment on first year undergraduate withdrawal. Journal of Further and Higher Education 30: 377-91.

Harrison, N., S. Agnew and J. Serido. 2015. Attitudes to debt among indebted undergraduates: A crossnational exploratory factor analysis. Journal of Economic Psychology 46: 62-73. http://doi.org/ 10.1016/j.joep.2014.11.005

Harrison, N. and Hatt, S. 2012. Expensive and failing? The role of student bursaries in widening participation and fair access in England. Studies in Higher Education 37(6): 695-712.

Harrison-Walker, L. J. 2010. Customer prioritization in higher education: Targeting "right" students for long-term profitability. Journal of Marketing for Higher Education 20(2): 191-208. http://doi.org/ $10.1080 / 08841241.2010 .526355$

Hodes, R. 2017. Questioning “fees must fall”. African Affairs 116(462): 140-150.

Jansen, J. 2017. As by the fire: The end of the South African university. Tafelberg: Cape Town.

Kerkvliet, J. and C. Nowell. 2014. Public subsidies, tuition, and public universities' choices of undergraduate acceptance and retention rates in the USA. Education Economics 22(6): 652-666. http://doi.org/10.1080/09645292.2012.659010

Kinnucan, H. W., Yuqing Zheng and G. Brehmer. 2006. State aid and student performance: A supplydemand analysis. Education Economics 14(4): 487-509. http://doi.org/10.1080/09645290 600854177 
Koch, S. E. and S. D. Foxcroft. 2003. A developmental focus to admissions testing: Admissions and placement standards development. South African Journal of Higher Education 17(3): 192-208.

Koen, C., M. Cele and A. Libhaber. 2006. Student activism and student exclusions in South Africa. International Journal of Educational Development 26(4): 404-414. http://doi.org/10.1016/ j.ijedudev.2005.09.009

Lebeau, Y., R. Stumpf, R. Brown, M. A. S. Lucchesi and M. Kwiek. 2012. Who shall pay for the public good? Comparative trends in the funding crisis of public higher education. Compare: A Journal of Comparative and International Education 42(1): 137-157.

Maistry, N. and T. J. M. McKay. 2016. Promoting energy efficiency in a South African university Journal of Energy in Southern Africa 27(3): 1-10.

McKay, T. J. M. 2016a. Academic success, language and the four year degree: A case study of a 2007 cohort. South African Journal of Higher Education 30(4): 190-209.

McKay, T. J. M. 2016b. Do tutors matter? Assessing the impact of tutors on academic performance of first year students. Journal of Student Affairs in Africa 4(1): 53-64.

Moloi, K. C. and R. R. Motaung. 2014. Challenges of total quality in education through quality assurance principles in one institution of higher education in South Africa. Mediterranean Journal of Social Sciences 5(1): 137.

Mngomezulu, S., R. Dhunpath and N. Munro. 2017. Does financial assistance undermine academic success? Experiences of "at risk" students in a South African university. Journal of Education (68): 131-148.

National Department of Education. 1997. Higher Education Act, Act No 101, 1997. Pretoria: Government Printer.

NDoE see National Department of Education.

Qonde, G. 2016. SA universities face financial struggle. ENCA http://www.enca.com/south-africa/sauniversities-face-financial-struggle (Accessed 15 Sept 2017).

Paliulis, N. K. and R. Labanauskis. 2015. Benchmarking as an Instrument for improvement of quality management in higher education. Business, Management and Education 13(1): 140.

Panigrahi, J. 2015. Growing private providers and constraints in the choice of higher education institutions: Impact on access to higher education. Economic Affairs: A Quarterly Journal of Economics 60(1): 41-47. http://doi.org/10.5958/0976-4666.2015.00004.2

Phelan, K. V. and J. E. Mills. 2011. An exploratory study of knowledge, skills, and abilities (KSAs) needed in undergraduate hospitality curriculums in the convention industry. Journal of Human Resources in Hospitality \& Tourism 10(1): 96-116. http://doi.org/10.1080/15332845.2010. 500244

Pillay, P. N. 2010. Higher education financing in East and Southern Africa. African Minds. https://0books.google.co.za.innopac.up.ac.za/books?hl=en\&lr=\&id=UOVLjNZWHKQC\&oi=fnd\&pg=P P2\&dq=Higher+Education+Financing + in + East + and + Southern + Africa\&ots $=8 \mathrm{kOsLtkm7b \& sig}=$ 1ULqdY68HJIIHwqtgx4T76IjckM

Oyelana, A. A. 2017. Effects of increase in tuition fees in the tertiary institutions of learning. International Journal of Educational Sciences 17(1-3): 140-147.

Richardson, M., C. Evans and G. Gbadamosi. 2009. Funding full-time study through part-time work. Journal of Education \& Work 22(4): 319-334. http://doi.org/10.1080/13639080903277394

Sader, S. B. and N. P. Gabela. 2017. Spatialities of widening participation: narratives of first year students receiving financial aid. South African Journal of Higher Education 31(1): 227-242.

Slater, M. 2009. The impact of financial aid on college GPA at three flagship public institutions. American Educational Research Journal 46: 782-815.

Styan, J.-B. 2014. The state of SA's tertiary education. Finweek: 10-15.

Van der Merwe, D. and M. de Beer. 2006. Challenges of student selection: Predicting academic performance. South African Journal of Higher Education 20(4): 547-562. 
Van Eeden, R., M. de Beer and C. H. Coetzee. 2001. Cognitive ability, learning potential and personality traits as predictors of academic achievement by engineering and other science and technology students. South African Journal of Higher Education 15(1): 171-179.

Walker, M. and F. Mkwananzi. 2015. Challenges in accessing higher education: A case study of marginalised young people in one South African informal settlement. International Journal of Educational Development 40: 40-49. http://doi.org/10.1016/j.ijedudev.2014.11.010

Welsch, D. M. and D. M. Zimmer. 2012. Do student migrations affect school performance? Evidence from Wisconsin's inter-district public school program. Economics of Education Review 31(1): 195-207. http://doi.org/10.1016/j.econedurev.2011.11.003

Westerman, J. W., L. A. Perez-Batres, B. S. Coffey and R. W. Pouder. 2011. The relationship between undergraduate attendance and performance revisited: Alignment of student and instructor goals. Decision Sciences Journal of Innovative Education 9(1): 49-67. http://doi.org/10.1111/j.15404609.2010.00294.x

Zaaiman, H. 1998. Selecting students for mathematics and science: The challenge facing higher education in South Africa. Human Sciences Research Council, 134 Pretorius Street Pretoria, Private Bag X41, Pretoria, South Africa 0001 (98.02 South African Rand). Web site: http://www.hsrc.ac.za. Retrieved from http://eric.ed.gov/?id=ED439908 